\title{
Honoré de Balzac, Sarrasine
}

\section{Marco Stupazzoni}

\section{(2) OpenEdition}

\section{Journals}

\section{Edizione digitale}

URL: https://journals.openedition.org/studifrancesi/4733

DOI: $10.4000 /$ studifrancesi.4733

ISSN: 2421-5856

\section{Editore}

Rosenberg \& Sellier

\section{Edizione cartacea}

Data di pubblicazione: 1 avril 2012

Paginazione: 164

ISSN: 0039-2944

\section{Notizia bibliografica digitale}

Marco Stupazzoni, «Honoré de Balzac, Sarrasine», Studi Francesi [Online], 166 (I | LVI) | 2012, online dal 30 novembre 2015, consultato il 19 novembre 2021. URL: http://journals.openedition.org/ studifrancesi/4733 ; DOI: https://doi.org/10.4000/studifrancesi.4733

\section{Questo documento è stato generato automaticamente il 19 novembre 2021.}

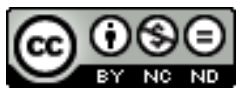

Studi Francesi è distribuita con Licenza Creative Commons Attribuzione - Non commerciale - Non opere derivate 4.0 Internazionale. 


\title{
Honoré de Balzac, Sarrasine
}

\author{
Marco Stupazzoni
}

\section{NOTIZIA}

HONORÉ DE BALZAC, Sarrasine, traduzione di Rosanna FARINAZZo, con uno scritto di Jean REBOUL, Milano, Feltrinelli, «I Classici Universale Economica Feltrinelli», 2010 pp. 61.

1 Su licenza della casa editrice ES/SE - che pubblicò in prima edizione questa traduzione di Sarrasine nel 1993 - viene riproposto all'attenzione del pubblico italiano il racconto balzachiano nella collana «Universale Economica. I Classici» dell'editore Feltrinelli.

2 Pubblicato, in prima edizione, nella «Revue de Paris» (21 e 28 novembre 1830) e successivamente inserito nei Contes philosophiques (1832) e nei Romans et contes philosophiques nel 1833, Sarrasine troverà la sua definitiva collocazione nel 1835 all'interno delle Scènes de la vie parisienne.

3 Nel saggio che segue il testo di Balzac - edito nel 1967 nei «Cahiers pour l'Analyse»("Sarrasine" ovvero la castrazione personificata, pp.51-60), Jean Reboul sottolinea il carattere onirico dell'opera, nella quale il narratore «si sforza di comunicare il sentimento di dissociazione che prova, che è il tema della novella e che sarà chiarito solo dal progressivo svelarsi della situazione» (p. 52).

4 Sarrasine di Balzac, osserva l'autore in conclusione, non ha equivalenti nella letteratura francese: è una novella «carica come una pila di forze tanto più distruttive, all'epoca, in quanto non erano affatto delucidate (e anzitutto all'autore stesso)» (p. 60). 